\title{
Prevalensi dan Distribusi Penderita Geographic Tongue pada Mahasiswa Fakultas Kedokteran Gigi Universitas Jember Angkatan 2014 - 2016 (Prevalence and Distribution of Geographic Tongue in Faculty Of Dentistry University of Jember Class of 2014-2016)
}

\author{
Pratita Ayu Pinasthika ${ }^{1}$, Ayu Mashartini $P^{2}$, Ristya Widy E $Y^{3}$ \\ ${ }^{1}$ Fakultas Kedokteran Gigi Universitas Jember \\ ${ }^{2}$ Bagian Oral Medicine Fakultas Kedokteran Gigi Universitas Jember \\ ${ }^{3}$ Bagian IImu Kedokteran Gigi Masyarakat Fakultas Kedokteran Gigi Universitas Jember \\ Jl. Kalimantan 37 Jember 68121 \\ E-mail: pratitaayup@icloud.com
}

\begin{abstract}
Background: Geographic tongue is a tongue disorder. The lesion is a asymptomatic and rarely lesion. These disorder is influenced by genetic and other predisposing factors. Previous studies had shown geographic tongue occured more frequently in female than male, in these study will be disscused how the prevalence and distribution by age and gender. Objective: To determine the prevalence and distribution of geographic tongue of University Students in Faculty of Dentistry University of Jember class of 2014-2016. Method: Was used descriptive epidemiology and the results presented in table and would be described. Result and Conclusion: Results showed the prevalence was 14 patients from 324 subjects or 4,3\%. The results showed higher in female than male and higher in 18 years old.
\end{abstract}

Keywords: Distribution, geographic tongue, prevalence.

\begin{abstract}
Abstrak
Latar Belakang : Geographic tongue merupakan sebuah kelainan pada lidah yang muncul berupa lesi asimptomatik yang jarang diketahui keberadaannya, oleh karena itu prevalensi dari kelainan ini cenderung kecil. Kelainan ini diduga kuat dipengaruhi oleh faktor genetik dan faktor predisposisi lainnya. Beberapa penelitian sebelumnya menunjukkan bahwa lesi ini lebih sering muncul pada perempuan daripada laki-laki. Pada penelitian ini ingin mengetahui bagaimana prevalensi dan distribusi menurut usia dan jenis kelaminnya. Tujuan penelitian : Mengetahui prevalensi geographic tongue dan distribusi menurut usia dan jenis kelaminnya pada mahasiswa Fakultas Kedokteran Gigi Universitas Jember angkatan 2014-2016. Metode : Metode yang digunakan adalah metode penelitian epidemiologi deskriptif, hasil yang didapatkan akan disajikan dalam tabel dan dijelaskan secara deskriptif. Hasil dan Simpulan: Hasil penelitian menunjukkan prevalensi dari geographic tongue sebanyak 14 penderita dari 324 subjek penelitian atau sebesar $4,3 \%$. 6 dari 14 penderita adalah laki-laki dan 8 penderita lainnya adalah perempuan. Kelainan ini muncul terbanyak pada usia 18 tahun.
\end{abstract}

Kata Kunci: Distribusi, geographic tongue, prevalensi. 


\section{Pendahuluan}

Geographic tongue atau benign migratory Geographic tongue atau benign migratory glossitis atau erythema migrains adalah suatu lesi inflamasi pada lidah yang bersifat jinak dan tidak memiliki kecenderungan berubah menjadi ganas. Kelainan ini sesuai dengan namanya, terjadi pada lidah khususnya pada bagian dorsum atau pada bagian lateral lidah. Lesi pada GT bersifat asimptomatik karena terdapat atrofi papilla atau depapilasi dari papilla filiformis yang mampu mengubah sensasi[1].

Etiologi dari lesi ini masih belum diketahui secara pasti, meskipun banyak penelitian dan studi yang meneliti tentang geographic tongue. Beberapa peneliti menyebutkan bahwa faktor genetik atau herediter berperan besar dalam lesi ini [2]. Faktor predisposisi juga mendukung terjadinya kelainan ini seperti defisiensi nutrisi, stress, dan lain-lain.

Prevalensi geographic tongue adalah sekitar 1-2,5\% [2], selain itu prevalensi lain dari kelainan ini dari beberapa negara antara lain, seperti di Amerika yaitu 1-14\%, Afrika Selatan $0,6 \%$, Brazil $27,7 \%$ dan India Selatan 5,71\% [3], di Indonesia sendiri pernah dilakukan sebuah penelitian tentang prevalensi geographic tongue di Fakultas Kedokteran Gigi Universitas Indonesia, pada penelitian tersebut didapatkan prevalensi geographic tongue sebesar $3,2 \%$ dari total 312 pasien [4]. Lesi ini lebih sering terjadi pada wanita dibandingkan pria diduga karena adanya pengaruh hormonal pada wanita dan juga adanya pengaruh dari siklus kontrasepsi yang digunakan oleh wanita, dari beberapa penelitian didapatkan hasil bahwa prevalensi geographic tongue pada wanita lebih tinggi dibandingkan pria [5].

Lesi geographic tongue secara klinis tampak berwarna kuning, putih atau abu-abu pada bagian tepinya dengan bentukan yang ireguler [6], lesi ini juga tampak seperti lingkaran merah dengan tepi berwarna putih yang tidak teratur pada bagian samping, maupun tengah lidah. Bercak merah merupakan suatu keadaan dimana adanya atrofi dari papilla filiformis dan batas putih dari bercak merah adalah papilla filiformis yang bergenerasi dan bercampur dengan keratin dan netrofil. Lesi ini biasanya muncul selama satu atau dua minggu lalu menghilang dan muncul kembali pada tempat yang berbeda dari lidah.

Geographic tongue merupakan lesi asimptomatik serta lesi ini bukan merupakan suatu kondisi dimana pasien selalu merasakan sakit akibat munculnya lesi tersebut, melainkan hanya saat terdapat faktor pencetus rasa sakitnya, seperti makanan yang pedas, panas dan asam serta minuman yang berkarbonasi atau beralkohol. Lesi geographic tongue juga kadang muncul saat periode menstruasi atau pada saat kondisi pasien sedang stress, selain itu kelainan ini dapat sembuh sendiri dan kemudian muncul lagi di tempat yang berbeda [7].

Geographic tongue merupakan sebuah kelainan yang mampu sembuh tanpa pengobatan, tetapi adanya lesi ini dapat menganggu aktifitas penderita apabila terlalu sering timbul. Lesi geographic tongue akan mengganggu fungsi mastikasi dan fungsi bicara dari penderita yang nantinya bisa menurunkan kualitas hidup penderita dan asupan gizi bagi penderita itu sendiri. Dari uraian diatas penulis merasa keberadaan dari lesi ini penting untuk diketahui untuk meningkatkan kesadaran penderita akan keberadaan lesi ini yang nantinya dapat dilakukan sebuah terapi atau perawatan untuk lesi ini.

Prevalensi rata-rata dari lesi ini sangat kecil, kemungkinan tingkat kesadaran penderita akan adanya lesi ini pada rongga mulutnya juga sangat rendah, lesi ini juga jarang menimbulkan rasa sakit sehingga jarang dikeluhkan oleh penderita, oleh sebab itu juga lesi ini jarang diketahui sebagai suatu abnormalitas pada tubuh penderita itu sendiri, oleh karena tingkat kesadaran penderita akan adanya lesi ini di dalam rongga mulutnya tergolong rendah, maka dari itu penulis ingin meneliti untuk menunjukkan keberadaan dari lesi ini.

Penelitian tentang geographic tongue dan hubungannya dengan tingkat depresi sudah pernah dilakukan sebelumnya di Fakultas Kedokteran Gigi Universitas Jember pada mahasiswa angkatan 2009, 2011, dan 2013. Namun belum pernah dilakukan penelitian terkait prevalensi dari geographic tongue pada mahasiswa Fakultas Kedokteran Gigi Universitas Jember angkatam 2014, 2015, dan 2016, oleh karena itu penulis ingin meneliti untuk mengetahui dan menyajikan data tentang prevalensi lesi ini.

Beberapa penelitian menyebutkan bahwa lesi ini lebih sering terjadi pada perempuan [5]. Hal tersebut membuat peneliti ingin tahu bagaimana prevalensi pada Mahasiswa Fakultas Kedokteran Gigi Universitas Jember khususnya pada mahasiswa laki-laki karena jumlah mahasiswa perempuan Fakultas Kedokteran Gigi Universitas Jember dari tahun 
ke tahun selalu lebih banyak dibandingkan dengan mahasiswa laki-laki. Selain itu juga, penulis bertujuan ingin ikut berkontribusi dalam penyediaan data penderita geographic tongue pada mahasiswa Fakultas Kedokteran Gigi angkatan 2014, 2015 dan 2016 yang belum pernah diteliti.

\section{Metode Penelitian}

Penelitian ini merupakan penelitian deskriptif, dimana setelah data diambil maka akan disajikan dalam bentuk tabel dan diagram lalu akan dideskripsikan dalam kalimat deskriptif. Penelitian dilakukan di Fakultas Kedokteran Gigi Universitas Jember dan bagian Oral Diagnosa RSGM Universitas Jember pada bulan Agustus sampai Desember 2016. Diawali dengan pembuatan persetujuan etik di Komisi Persetujuan Etik Fakultas Kedokteran Universitas Jember, diikuti dengan memberikan kuesioner dan informed consent pada subjek penelitian lalu dilakukan pemeriksaan pada subjek penelitian.

\section{Hasil Penelitian}

Penelitian mengenai prevalensi dan distribusi geographic tongue pada Mahasiswa Fakultas Kedokteran Gigi Universitas Jember Angkatan 2014-2016 telah dilakukan pada bulan Agustus sampai Desember 2016 di Fakultas Kedokteran Gigi Universitas Jember. Data yang diambil dari penelitian ini adalah prevalensi geographic tongue, distribusi berdasarkan usia dan jenis kelamin yang muncul pada masingmasing angkatan, yakni angkatan 2014, 2015, dan 2016.

Data prevalensi dan distribusi penderita geographic tongue ditampilkan dalam bentuk tabel. Prevalensi penderita geographic tongue diolah menjadi tabel yang menampilkan prevalensi penderita geographic tongue dari masing-masing angkatan yakni angkatan 2014, 2015 dan 2016, prevalensi menurut usia, jenis kelamin dan keluhan rasa sakit. Distribusi penderita geographic tongue berdasarkan usia, jenis kelamin dan keluhan rasa sakit diolah dan disajikan dalam bentuk tabel. Hasil penelitian yang telah dilakukan menunjukkan bahwa dari jumlah total subjek mahasiswa yang diteliti yakni 324 orang, didapatkan 14 orang penderita geographic tongue, sehingga didapatkan total prevalensi yaitu 4,3\% (Tabel 1).
Tabel 1. Prevalensi Geographic tongue pada Mahasiswa Fakultas Kedokteran Gigi Universitas Jember Angkatan 2014-2016.

\begin{tabular}{|c|c|c|c|}
\hline \multirow[b]{2}{*}{ Angkatan } & \multicolumn{2}{|c|}{ Prevalensi } & \multirow[b]{2}{*}{ Persentase } \\
\hline & $\sum_{\text {Populasi }}$ & $\begin{array}{c}\sum \text { Penderita } \\
\text { Geographic } \\
\text { tongue }\end{array}$ & \\
\hline 2014 & 83 & 2 & $2,4 \%$ \\
\hline 2015 & 123 & 6 & $4,9 \%$ \\
\hline 2016 & 118 & 6 & $5,0 \%$ \\
\hline Total & 324 & 14 & $4,3 \%$ \\
\hline
\end{tabular}

Tabel 2. Prevalensi geographic tongue menurut jenis kelamin pada mahasiswa Fakultas Kedokteran Gigi Universitas Jember Angkatan 2014-2016

\begin{tabular}{cccc}
\hline $\begin{array}{c}\text { Jenis } \\
\text { Kelamin }\end{array}$ & Populasi & $\begin{array}{c}\text { Geographic } \\
\text { tongue }\end{array}$ & Prevalensi \\
\hline Laki-laki & 55 & 6 & $10,9 \%$ \\
Perempuan & 269 & 8 & $2,9 \%$ \\
\hline
\end{tabular}

Didapatkan jumlah prevalensi
geographic tongue lebih besar pada laki-laki dibandingkan perempuan seperti dapat dilihat pada Tabel 2.

Tabel 3. Prevalensi geographic tongue menurut usia pada Mahasiswa Fakultas Kedokteran Gigi Universitas Jember Angkatan 2014-2016

\begin{tabular}{cccc}
\hline \multicolumn{4}{c}{ Prevalensi } \\
Usia & $\sum_{\text {Populasi }}$ & $\begin{array}{c}\sum \text { Penderita } \\
\text { Geographic } \\
\text { tongue }\end{array}$ & Prevalensi \\
\hline & & & \\
18 & 97 & 6 & $6,1 \%$ \\
19 & 116 & 4 & $3,4 \%$ \\
20 & 111 & 4 & $3,6 \%$ \\
\hline
\end{tabular}

Tabel 3 menunjukkan hasil bahwa penderita geographic tongue muncul paling banyak pada usia 18 tahun.

Tabel 4. Prevalensi geographic tongue menurut keluhan rasa sakit pada Mahasiswa Fakultas Kedokteran Gigi Universitas Jember Angkatan 20142016

\begin{tabular}{ccc}
\hline $\begin{array}{c}\text { Geographic } \\
\text { tongue }\end{array}$ & $\sum$ Penderita & Prevalensi \\
\hline Keluhan Sakit & 3 & $0,9 \%$ \\
$\begin{array}{c}\text { Keluhan Tidak } \\
\text { Sakit }\end{array}$ & 11 & $3,3 \%$ \\
\hline
\end{tabular}


Pada penelitian ini ditemukan 3 orang mengeluhkan adanya simptom atau rasa sakit sedangkan 11 lainnya tidak memiliki simptom seperti dapat dilihat pada Tabel 4.

Tabel 5. Distribusi penderita geographic tongue berdasarkan jenis kelamin.

\begin{tabular}{ccc}
\hline Jenis Kelamin & $\begin{array}{c}\text { Geographic } \\
\text { tongue }\end{array}$ & Persentase \\
\hline Laki-laki & 6 & $42,86 \%$ \\
Perempuan & 8 & $57,14 \%$ \\
Jumlah & 14 & $100 \%$ \\
\hline
\end{tabular}

Pada Tabel 5 distribusi penderita geographic tongue muncul lebih besar pada perempuan dibandingkan laki-laki, berbeda dengan hasil berdasarkan perhitungan prevalensi.

Tabel 6. Distribusi penderita geographic tongue berdasarkan usia.

\begin{tabular}{ccc}
\hline Usia & $\begin{array}{c}\text { Geographic } \\
\text { tongue }\end{array}$ & Persentase \\
\hline 18 & 6 & $42.86 \%$ \\
19 & 4 & $28.57 \%$ \\
20 & 4 & $28.57 \%$ \\
Jumlah & 14 & $100 \%$ \\
\hline
\end{tabular}

Pada perhitungan distribusi didapatkan hasil yang sama dengan prevalensi yakni, penderita geographic tongue muncul paling banyak pada usia 18 tahun (Tabel 6).

Tabel 7. Distribusi penderita geographic tongue berdasarkan keluhan rasa sakit.

\begin{tabular}{ccc}
\hline $\begin{array}{c}\text { Geographic } \\
\text { tongue }\end{array}$ & $\sum_{\text {penderita }}$ & Persentase \\
\hline Keluhan Sakit & 3 & $21.43 \%$ \\
Keluhan Tidak & 11 & $78.57 \%$ \\
Sakit & 14 & $100 \%$ \\
\hline Jumlah & &
\end{tabular}

Distribusi berdasarkan keluhan rasa sakit menunjukkan 3 orang mengeluhkan adanya rasa sakit dan 11 lainnya tidak mengeluhkan adanya rasa sakit (Tabel 7 ).

\section{Pembahasan}

Prevalensi dari geographic tongue bervariasi, ditemukan pada beberapa penelitian sebelumnya di berbagai negara, seperti di Amerika 1-14\%, Afrika Selatan 0,6\%, Brazil 27,7\% dan India Selatan 5,71\% [3]. Prevalensi geographic tongue di FKG Universitas Indonesia sebesar $3,2 \%$ dari total 312 pasien [4]. Variasi prevalensi tersebut juga muncul dari penelitian ini yakni di Universitas Jember yang didapatkan angka prevalensinya sebesar $4,3 \%$ dari jumlah total 324 subjek penelitian. Prevalensi dari masing-masing angkatan sendiri didapatkan dari angkatan 2014 sebanyak 2 orang atau sebesar $2,4 \%$ dari 83 subjek penelitian, kedua penderita adalah laki-laki. Pada angkatan 2015 sebanyak 6 orang atau sebesar 4,9\% dari 123 subjek penelitian, 4 orang diantaranya adalah perempuan dan 1 orang laki-laki. Sedangkan pada angkatan 2016 sebanyak 6 orang atau sebesar $5,0 \%$ dari 118 subjek penelitian, 5 orang diantaranya adalah perempuan dan 1 orang laki-laki.

Geographic tongue ditandai dengan periode eksaserbasi dan remisi. Periode eksaserbasi merupakan suatu periode dimana lesi kambuh setelah periode remisi atau masa penyembuhan. Pada periode remisi biasanya lesi jarang atau hanya sedikit tampak, karena sedang dalam proses penyembuhan. Dengan adanya periode eksaserbasi dan remisi dari kelainan ini, maka hasil dari penelitian, prevalensi geographic tongue sebesar 4,3\% diduga dapat berubah karena pada saat penelitian penderita sedang dalam masa remisi. Selain itu didukung oleh ketidaktahuan penderita terhadap kelainan yang muncul pada lidahnya sehingga membuat lesi tidak terlihat pada saat dilakukan penelitian. Hal tersebut mungkin terjadi karena geographic tongue merupakan suatu kelainan yang bersifat asimptomatik dan jarang menimbulkan keluhan atau simptom.

Geographic tongue lebih sering muncul atau terjadi pada perempuan dibandingkan lakilaki[5]. Ditemukan pada penelitian ini bahwa distribusi penderita perempuan berjumlah lebih banyak dibandingkan laki-laki, yakni 8 orang perempuan dan 6 orang laki-laki. Namun perbandingan tersebut tidak dapat dijadikan sebagai acuan karena jumlah subjek penelitian berjenis kelamin perempuan lebih banyak dibandingkan jumlah subjek penelitian laki-laki. Apabila dilakukan penghitungan dengan menggunakan rumus prevalensi, jumlah penderita geographic tongue muncul lebih besar pada laki-laki dibandingkan dengan jumlah penderita pada perempuan. Jumlah mahasiswa laki-laki pada subjek penelitian ini adalah 55 orang, sedangkan jumlah mahasiswa perempuan adalah 269 orang, apabila dilakukan penghitungan menggunakan rumus prevalensi, 
maka jumlah prevalensi pada laki-laki lebih besar yakni sebesar $10,9 \%$, sedangkan jumlah prevalensi pada perempuan yakni $2,9 \%$. Perbandingan jumlah dari uraian tersebut tidak dapat dijadikan sebagai acuan karena jumlah subjek penelitian antara laki-laki dan perempuan tidak proporsional.

Prevalensi penderita geographic tongue menurut usia ditemukan dengan jumlah terbanyak pada usia 18 tahun dengan jumlah prevalensi $6,1 \%$. Hal ini terjadi karena jumlah penderita usia 18 tahun lebih banyak dibandingkan usia 19 dan 20 tahun. Prevalensi usia yang muncul pada penelitian ini hanya usia 18, 19 dan 20 tahun pada saat penelitian berlangsung. Sedangkan distribusi geographic tongue menurut usia dari penelitian ini didapatkan penderita geographic tongue berusia 18 tahun sebesar $42,86 \%$, usia 19 tahun sebesar $28,57 \%$ dan usia 20 tahun sebesar $28,57 \%$. Menurut pembagian kelompok usia dari Depkes RI tahun 2009, dari penelitian ini hanya didapatkan usia penderita dari kelompok usia masa remaja akhir yakni usia 17-25 tahun, hal ini dikarenakan usia mahasiswa pada umumnya memasuki perguruan tinggi adalah usia 16-25 tahun. Dari hasil anamnesis, sebagian penderita tidak mengetahui secara pasti kapan kelainan ini muncul pada lidah mereka, namun terdapat penderita yang mengetahui keberadaan dari kelainan ini sejak masa Sekolah Menengah Pertama (SMP) atau masa Sekolah Menengah Atas (SMA) atau apabila ditinjau berdasarkan kelompok usia menurut Depkes RI tahun 2009 adalah kelompok usia remaja awal yakni usia 12-16 tahun.

Pada penelitian ini didapatkan hasil bahwa geographic tongue muncul dengan jumlah terbanyak pada usia 18 tahun. Hal ini dipengaruhi juga oleh banyaknya jumlah penderita geographic tongue pada angkatan 2016 yakni mahasiswa baru yang diduga dipengaruhi oleh faktor stress akibat penyesuaian atau adaptasi terhadap perkuliahan. Stressor pada mahasiswa baru dapat dikelompokkan menjadi 3 kategori yakni, stressor akademis, sosial dan personal [8]. Stressor akademis membuat mahasiswa baru mengalami perubahan situasi dan pola belajar serta suasana lingkungan yang berubah dari sekolah menuju perguruan tinggi, hal ini menjadi sebuah tantangan baru yang tidak mudah untuk dihadapi bagi seorang mahasiswa baru, sehingga stres mampu memberikan dampak pada psikis maupun fisik dari seorang mahasiswa baru. Sedikit berbeda dengan angkatan 2015 dan 2014 yang juga memiliki beban stress yang lebih berat tetapi mereka sudah melewati masa adaptasi dengan lingkungan baru atau lingkungan perkuliahan, sehingga mereka lebih mampu mengatasi pemicu stress yang muncul, meskipun pada angkatan 2015 didapatkan 6 orang penderita geographic tongue, namun frekuensi ekserbasi pada penderita dari angkatan 2015 lebih jarang dibandingkan dengan mahasiswa baru angkatan 2016.

Geographic tongue biasanya menimbulkan simptom atau keluhan pada anakanak dan jarang dialami oleh penderita usia dewasa muda, karena anak-anak lebih tidak mampu mentolerir rasa sakit dibandingkan dengan orang yang sudah lebih dewasa, selain itu juga biasanya lesi ini tidak memerlukan perawatan dan dapat sembuh sendiri [9]. Namun pada kuesioner penelitian beberapa penderita geographic tongue mengeluhkan adanya rasa sakit dari munculnya lesi. Prevalensi keluhan rasa sakit muncul sebanyak $0,9 \%$. Penderita mengaku lesi akan terasa sakit apabila mengonsumsi makanan pedas, asin, asam dan panas serta saat meminum minuman yang panas, asam, beralkohol dan berkarbonasi. Dari penelitian ini didapatkan 3 dari 14 orang penderita geographic tongue pada penelitian ini mengeluhkan sakit pada lidahnya saat faktor pencetusnya muncul seperti dapat dilihat dari tabel 4.

Penderita yang mengeluhkan munculnya rasa sakit pada lesi mengaku bahwa dari rentang waktu eksaserbasi, tidak selama periode ekserbasi tersebut lesi terasa sakit. Lesi hanya terasa sakit apabila terkena salah satu dari jenis pemicunya seperti makanan pedas, asam, asin, dan panas atau minuman yang beralkohol dan berkarbonasi. Beberapa penderita mengaku bahwa lidahnya terasa panas dan perih saat mengonsumsi makanan panas, pedas serta meminum minuman yang berkarbonasi atau minuman panas dan asam. Hal ini diduga karena geographic tongue merupakan suatu lesi dimana papilla filiformisnya mengalami atrofi atau depapilasi sehingga mungkin terjadi gangguan pada fungsi pengecapan terhadap beberapa jenis makanan dan minuman seperti makanan yang pedas, asam, asin serta minuman yang berkarbonasi atau beralkohol.

\section{Simpulan dan Saran}

Hasil penelitian yang telah dilakukan didapatkan kesimpulan, yaitu prevalensi dan distribusi 
penderita Geographic tongue pada mahasiswa Fakultas Kedokteran Gigi Universitas Jember angkatan 2014-2016 adalah: (1)Prevalensi total geographic tongue dari ketiga angkatan tersebut adalah 14 penderita atau $4,3 \%$ dari total 324 subjek yang diteliti, didapatkan 2 penderita atau $2,4 \%$ dari angkatan 2014,6 penderita atau $4,9 \%$ dari angkatan 2015 dan 6 penderita atau $5 \%$ dari angkatan 2016. (2) Distribusi penderita geographic tongue menurut usia, didapatkan data dengan jumlah paling tinggi terjadi pada usia 18 tahun dengan jumlah 6 penderita atau $42,86 \%$. (3) Distribusi penderita geographic tongue menurut jenis kelamin ditemukan 8 penderita atau $57,14 \%$ pada perempuan sedangkan pada laki-laki 6 penderita atau $42,86 \%$.

Saran pada penelitian ini adalah perlu dilakukan penelitian lebih lanjut untuk mengetahui apa benar bahwa geographic tongue lebih sering terjadi pada perempuan, dan bagaimana keterkaitannya. Serta diharapkan dapat dilakukan penelitian lebih lanjut pada angkatan-angkatan yang lainnya untuk mengetahui bagaimana epidemiologi geographic tongue pada lingkungan Fakultas Kedokteran Gigi Universitas Jember.

\section{Daftar Pustaka}

[1] Musaad, A. H, Abuaffan, A. H, dan Khier E. 2015. Prevalence of Fissured and Geographic Tongue Abnormalities among University Students in Khartoum State,
Sudan. Enz Eng, 5:1.

[2] Burket, Greenberg, Glick, dan Ship. 2008. Burket's Oral Medicine Elevent Edition. Canada: BC Decker Inc.

[3] Hamissi, J. H., Feahin, M. E., dan Hamissi Z., 2015. Treatment of Geographic tongue Superimposing Fissured Tongue: A literature review with case report. Sch. J. Dent. Sci. 2 (7): 409-413.

[4] Elisabeth, M., 2008. Prevalensi dan distribusi fissure tongue, geographic tongue, median rhomboid gossitis dan hairy tongue pada pasien Rumah Sakit Gigi dan Mulut Pendidikan Fakultas Kedokteran Gigi Universitas Indonesia berdasarkan usia dan jenis kelamin. Jakarta: Skripsi Sarjana pada FKG UI.

[5] Jainkittivong, A. \& Langlais, R. P. 2005. Geographic tongue: Clinical Characteristics of 188 Cases. J Contemp Dent Pract. 1 (6): 123-135.

[6] Shahzad, M., Sattar, A., dan Ali, S. M. F. 2014. Geographic tongue: Case Report And Literature Review. Pakistan Oral \& Dental J Vol 34, No. 3.

[7] Kelsch, R. D. 2014. Geographic tongue: Background, Pathophysiology. Epidemiology.

[8] Suranadi, L. 2012. Manajemen Stress Mahasiswa Baru. Jurnal Kesehatan Prima Vol. 6(2).

[9] Mattoo, K. A. \& Nagaraj, K. 2014. Symptomatic Benign Migratory Glossitis, IJRID Vol.4 Issue 4.. 